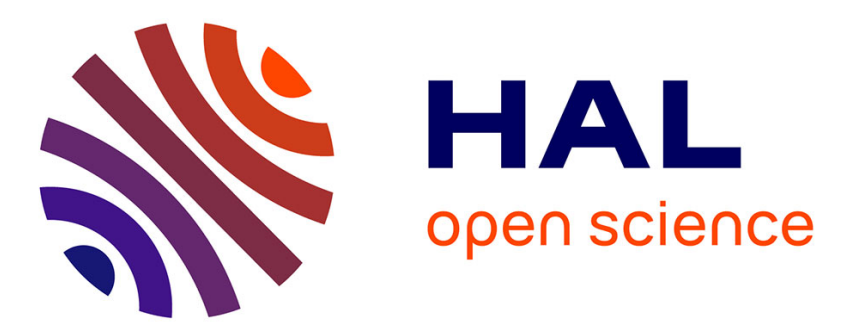

\title{
The French eco-neighbourhood evaluation model: Contributions to sustainable city making and to the evolution of urban practices
}

Cedissia About, Daniela Belziti, Bruno Bessis, Franck Faucheux, Thibaut Le Sceller, François-Xavier Monaco, Pierre Pech

\section{To cite this version:}

Cedissia About, Daniela Belziti, Bruno Bessis, Franck Faucheux, Thibaut Le Sceller, et al.. The French eco-neighbourhood evaluation model: Contributions to sustainable city making and to the evolution of urban practices. Journal of Environmental Management, 2016, 10.1016/j.jenvman.2016.03.036 . hal-02357697

\section{HAL Id: hal-02357697 \\ https://hal.science/hal-02357697}

Submitted on 19 Nov 2021

HAL is a multi-disciplinary open access archive for the deposit and dissemination of scientific research documents, whether they are published or not. The documents may come from teaching and research institutions in France or abroad, or from public or private research centers.
L'archive ouverte pluridisciplinaire HAL, est destinée au dépôt et à la diffusion de documents scientifiques de niveau recherche, publiés ou non, émanant des établissements d'enseignement et de recherche français ou étrangers, des laboratoires publics ou privés. 
Review

\title{
The French eco-neighbourhood evaluation model: Contributions to sustainable city making and to the evolution of urban practices
}

\author{
Cédissia About-de Chastenet ${ }^{a}$, Daniela Belziti ${ }^{b}$, Bruno Bessis ${ }^{c}$, Franck Faucheux ${ }^{d}$, \\ Thibaut Le Sceller ${ }^{\mathrm{e}}$, François-Xavier Monaco ${ }^{\mathrm{e}}$, Pierre Pech ${ }^{\mathrm{f}, *}$ \\ a Paris City Council, France \\ b Sustainable Urban Planning, Centre Scientifique et Technique du Bâtiment (CSTB), France \\ ${ }^{c}$ Ministry in charge of Urban Planning, France \\ ${ }^{\mathrm{d}}$ National Agency for Urban Renovation (ANRU), France \\ e Les EnR, France \\ ${ }^{\mathrm{f}}$ University Paris 1 Panthéon-Sorbonne, LADYSS CNRS UMR 7533, France
}

\section{A R T I C L E I N F O}

\section{Article history:}

Received 23 December 2015

Received in revised form

21 March 2016

Accepted 22 March 2016

\section{Keywords:}

Eco-neighbourhoods

Urban project

Sustainable city

Assessment tool

\begin{abstract}
A B S T R A C T
In this article we discuss whether the French eco-neighbourhood policy tool may be considered as an original experimentation in sustainable urban planning. From scientific literature across a number of countries and especially in European context, we present what kind of policies may achieve econeighbourhoods. Then we present what the French framework is, and what tools to promote and elaborate eco-neighbourhoods there are in France. Thirdly, in fact, both French policies, national and local, concerning eco-neighbourhood projects, seem to integrate means of assessing urban projects and this assessment achieves a kind of certification. While the Ministry in charge of Urban Planning has developed the national EcoQuartier ("EcoNeighbourhood" in English) certification, the City of Paris and other local authorities have designed similar tools, which integrate a large number of parameters dealing with urban sustainability and which are designed to evolve over time. Finally, we discuss whether the French tool is really original and whether it prefigures new practices in the field of sustainable urban development.
\end{abstract}

(c) 2016 Elsevier Ltd. All rights reserved.

\section{Contents}

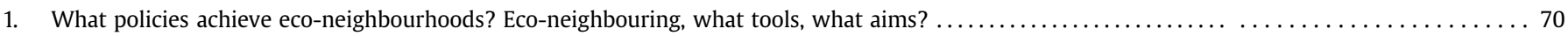

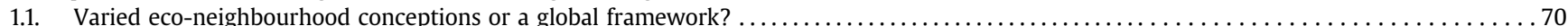

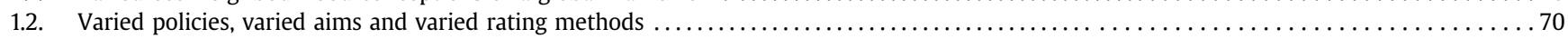

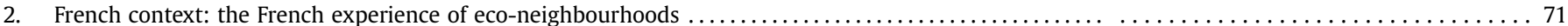

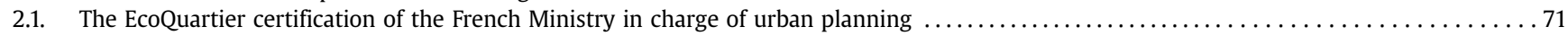

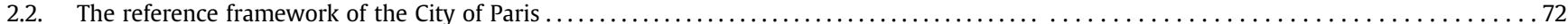

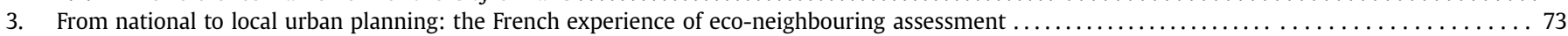

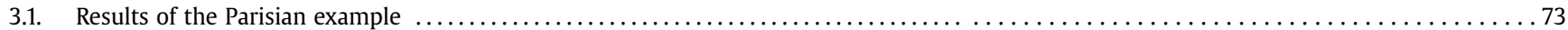

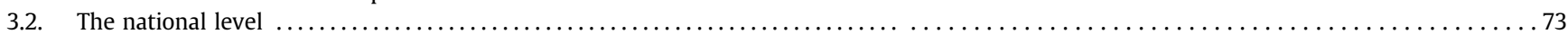

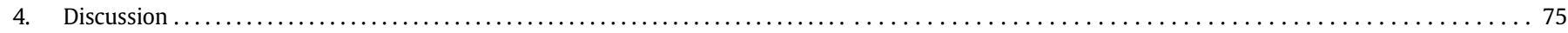

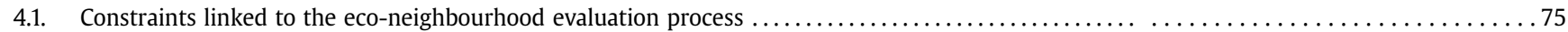

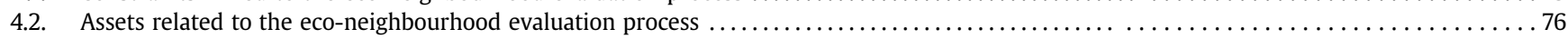

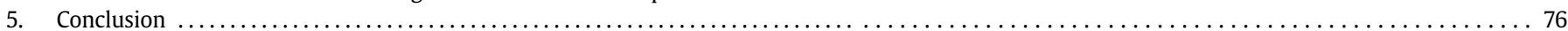

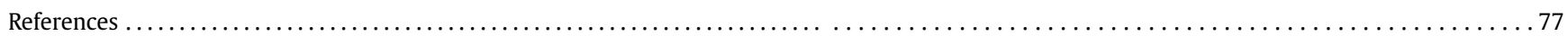

\footnotetext{
* Corresponding author.

E-mail address: pech@univ-paris1.fr (P. Pech).
} 


\section{What policies achieve eco-neighbourhoods? Eco- neighbouring, what tools, what aims?}

\subsection{Varied eco-neighbourhood conceptions or a global framework?}

Across a number of countries and especially in European context, the whole approach of urban planning is changing with sustainable development principles (Table 1). More especially, the framework of the eco-neighbourhood or eco-city is growing in importance because it seems to be the most complete and holistic integration of the urban sustainable principle (Boutaud, 2009; Holman, 2009; Jégou, 2011; Pickett et al., 2011; Wang et al., 2011; Douglas, 2014; Joss, 2015). In Asia or other emergent countries, sustainable city guiding principles are controlling these new city developments, primarily for the design of the eco-district/ neighbourhood or the eco-city (Andersson, 2006, Holden, 2006; Grimm et al., 2008; Wang et al., 2011; Li et al., 2011; Xiaosai et al., 2013; Joss, 2015).

Although the first eco-neighbourhood developments can be traced back to the 1960s, (Boutaud, 2009; Joss, 2015), it is only those completed in the early 2000s and afterwards which have really established themselves as urban planning frameworks of inclusive neighbourhoods and sustainable city building (Boutaud, 2009; Jégou, 2011; Li et al., 2011; Pandis and Brandt, 2011; Joss, 2015). In every part of the world, from Moscow (Paiho et al., 2014), to Tianjin near Beijing (Zhao et al., 2009; Caprotti, 2014), and even in Masdar, in the desert near Abu Dhabi (Premalatha et al., 2013), these frameworks of urban development have become global. The terms of the concept concern at least two levels of scale: the neighbourhood, so called eco-district or eco-neighbourhood, and the level of a whole city, so called eco-city (Boutaud, 2009;
Jégou, 2011; Wang et al., 2011; Douglas, 2014; Joss, 2015). Some make a distinction between eco-neighbourhood and eco-district, the former being smaller. In the same way, some integrate ecocity into smart city, the latter also known as the digital city. In this paper, our survey concerns the level of neighbourhoods and we will not distinguish between eco-district and eco-neighbourhood, so the only concept used will be eco-neighbourhood (Komeily and Srinivasan, 2015; Wangel et al., 2016). This definition may seem broad, but scientists and urban managers and planners investigate means or criteria and indicators for assessing the sustainability of neighbourhoods.

Is there a single global framework for eco-neighbourhoods?

\subsection{Varied policies, varied aims and varied rating methods}

Rating systems are often the best way to assess the objectivity of sustainable scopes of urban projects and policies. Most frequently, evaluation and certification procedures accompanying the construction of buildings are codified, particularly in the area of energy efficiency but also in that of eco-efficiency such as life-cycle and ecological footprints (Cole, 1998; Gonzalez and Zamarreno, 2005; Ding, 2008; Utama and Gheewala, 2008; Korolijaa et al., 2011; Burdova and Vilcekova, 2012; Ewing et al., 2012; Teng and Wu, 2014). Actually, important developments concern these procedures in the field of urban planning (Smyth et al., 2007; Chelzen and Pech, 2011; Caprotti, 2014; Joss, 2015). The evaluation of urban projects and the production of indicators have thus proven to be a challenge in both technical and scientific terms (Boulanger and Bréchet, 2005; Boulanger and Lazzeri, 2006; Smyth et al., 2007; Caprotti, 2014) due to the complexity of the approach employed, which is based on differing types of data and predefined criteria. A

Table 1

Theme distribution covered by eco-neighbourhoods in international publications.

\begin{tabular}{|c|c|c|c|}
\hline Kind of tool & Domains & Evaluators & References \\
\hline \multirow[t]{11}{*}{$\begin{array}{l}\text { Indicators } \\
\text { or index }\end{array}$} & Life cycle assessment & $\begin{array}{l}\text { Independant or academic or official } \\
\text { experts }\end{array}$ & $\begin{array}{l}\text { Forsberg and Von Malmborg, 2004; Erlandson and Levin, 2005; Bin and } \\
\text { Parker, 2012; Teng and Wu, 2014; }\end{array}$ \\
\hline & Energy consumption & $\begin{array}{l}\text { Independant or academic or official } \\
\text { experts }\end{array}$ & $\begin{array}{l}\text { Forsberg and Von Malmborg, 2004; Erlandson and Levin, 2005; } \\
\text { Malmqvist and Glaumann, 2009; Weber and Shah, 2011; Teng and Wu, } \\
\text { 2014; }\end{array}$ \\
\hline & Carbon consumption & $\begin{array}{l}\text { Independant or academic or official } \\
\text { experts }\end{array}$ & $\begin{array}{l}\text { Gonzalez and Navarro, 2006; Junnila et al., 2006; Gustavsson et al., } \\
\text { 2010; Kneifel, 2010; Monahan and Powell, 2011; Ouyang et al., 2011; } \\
\text { Hong et al., 2012; Rinne and Syri, 2013; Li et al., } 2013\end{array}$ \\
\hline & Waste recycling & $\begin{array}{l}\text { Independant or academic or official } \\
\text { experts }\end{array}$ & Erlandson and Levin, 2005; \\
\hline & Ecological footprints & $\begin{array}{l}\text { Independant or academic or official } \\
\text { experts }\end{array}$ & $\begin{array}{l}\text { Chambers et al., 2004; Li et al., 2010; Wang et al., 2011; Bin and Parker, } \\
\text { 2012; Solís-Guzmán et al., } 2013\end{array}$ \\
\hline & Water resources management & $\begin{array}{l}\text { Independant or academic or official } \\
\text { experts }\end{array}$ & Forsberg and Von Malmborg, 2004; Bai et al., 2011 \\
\hline & Economic development & $\begin{array}{l}\text { Independant or academic or official } \\
\text { experts }\end{array}$ & $\begin{array}{l}\text { Mascarenhas et al., 2010; Wang et al., 2011; Bulkeley and Castan-Broto, } \\
2012\end{array}$ \\
\hline & Social indicators & $\begin{array}{l}\text { Independant or academic or official } \\
\text { experts }\end{array}$ & $\begin{array}{l}\text { Mascarenhas et al., 2010; Wang et al., 2011; Bulkeley and Castan-Broto, } \\
2012\end{array}$ \\
\hline & Quality life & $\begin{array}{l}\text { Independant or academic or official } \\
\text { experts }\end{array}$ & McMahon, 2002 \\
\hline & General data & $\begin{array}{l}\text { Independant or academic or official } \\
\text { experts }\end{array}$ & $\begin{array}{l}\text { Forsberg and Von Malmborg, 2004; Holden, 2006; Mascarenhas et al., } \\
\text { 2010; Tanguay et al., 2010; Wang et al., 2011; Bulkeley and Castan- } \\
\text { Broto, 2012; Moreno Pires et al., } 2014\end{array}$ \\
\hline & Ecological efficiency & $\begin{array}{l}\text { Independant or academic or official } \\
\text { experts }\end{array}$ & Erlandson and Levin, 2005; Li et al., 2010; Solís-Guzmán et al., 2013 \\
\hline \multirow[t]{3}{*}{$\begin{array}{l}\text { Specific } \\
\text { assessment }\end{array}$} & Ecoservices & $\begin{array}{l}\text { Independant or academic or official } \\
\text { experts }\end{array}$ & Bai et al., 2011; Wang et al., 2011 \\
\hline & Cost benefit evaluation & $\begin{array}{l}\text { Independant or academic or official } \\
\text { experts }\end{array}$ & Bai et al., 2011 \\
\hline & Models & $\begin{array}{l}\text { Independant or academic or official } \\
\text { experts }\end{array}$ & $\begin{array}{l}\text { Erlandson and Levin, 2005; Bai et al., 2011; Xuan et al., 2012; Douglas, } \\
\text { 2014; Moreno Pires et al., 2014; Neirotti et al., } 2014\end{array}$ \\
\hline General tool & Integrative system & $\begin{array}{l}\text { Independant or academic or official } \\
\text { experts } \\
\text { Local deliberations }\end{array}$ & $\begin{array}{l}\text { Pickett et al., 2001; Wang et al., 2011; Riera Pérez and Rey, 2013; } \\
\text { Caprotti, 2014; Moreno Pires et al., 2014; Neirotti et al., } 2014 \\
\text { Mascarenhas et al., 2010; Holden, 2013; Douglas, } 2014\end{array}$ \\
\hline
\end{tabular}


real interest in the production of urban project evaluation processes has progressively emerged. The variety of these processes is due to the multiplicity of professional, academic and institutional actors involved. Today, establishing an exhaustive list of all the initiatives has become complex due to their constant evolution, a lack of organized communication, and the informal distribution (or lack of distribution) of some of them. Taking into account both the evaluation outcomes that these procedures dealt with and the types of organizations that have developed them, we are nonetheless able to establish a rich overview of these initiatives.

Most eco-neighbourhoods are defined by thematic parameters in which criteria related to energy and carbon performance are dominant (Table 1). As demonstrated by Kien and Fernandez (2014), a large number of reference documents rely primarily on technological criteria. For instance, Fujisawa (Kien and Fernandez, 2014), a neighbourhood developed by Panasonic in Japan, will be required to accommodate 1000 people as well as present a showcase for energy technologies. Similarly, Masdar (Walsh, 2011; Cugurolo, 2013; Caprotti, 2014), also constitutes a green city prototype. Sze and Gambirazzio (2013) state that Masdar City is the symbol of an eco-city designed without integrating ecology and without bottom-up decision making. Caprotti (2014) asks similar questions about the case of Tianjin, which is an instrument of political marketing producing new rich and poor social classes. Most often, eco-neighbouring results in gentrification.

In addition, evaluation means concern the project, but most of the projects do not provide means of monitoring the evolution of the neighbourhood when it is built. This ought to create the challenge for contracting authorities of determining which performance level to achieve and the means of maintaining this level over time.

As shown by Li et al. (2011), Caprotti (2014), and Joss (2015) there are few eco-neighbourhoods for which a multi-criteria (and therefore holistic or integrated) sustainable development approach is proposed (Perez and Rey, 2013). European policies and frameworks are variable but they provide indicators and assessment meanings (Table 2). Through the French experience, this paper explores criteria for such an integrated evaluation framework for eco-neighbourhoods.

This article brings together writers from different backgrounds, all of whom are involved in evaluation processes, including operators with the City of Paris, the Ministry in charge of Urban Planning, researchers from various organizations, and a private design and planning firm (Les EnR).

\section{French context: the French experience of eco- neighbourhoods}

In France especially (Boutaud, 2009), some key players, such as the French state (through its Ministry in charge of Urban Planning) and the City of Paris, have developed indicator-based assessment procedures for the evaluation of urban projects.

What are the effects of evaluation on project monitoring or urban land management? In 2009, the French Ministry in charge of urban planning commissioned a study to identify and critically analyse evaluation indicators for eco-neighbourhoods. First, 656 potentially relevant indicators for the assessment of econeighbourhoods were listed, $35 \%$ of which dealt with environmental issues. However, although the identified number of indicators seems large enough to cover the entire range of sustainable development issues, they are nonetheless insufficient from a qualitative point of view.

Secondly, these indicators are of different kinds: qualitative, descriptive, quantitative, etc. These are essentially indicators of means that focus on quantitative evaluation tools used to achieve levels of performance that are themselves poorly quantified. Indeed, in most cases, the evaluation proposed by existing approaches relies more on recommendations/guidance, or on monitoring measures, than on indicators. Beyond environmental aspects, indicators from other dimensions of sustainable development such as urban morphological parameters (functional diversity, density, urban and landscape quality, etc.), social measures (social diversity, welfare, etc.), and economic measures (financial feasibility, overall cost, control of land, economic dynamics, etc.) are either missing or insufficiently representative. This finding highlights the lack of strong points of reference for evaluating some components of concern as well as the need for progress.

\subsection{The EcoQuartier certification of the French Ministry in charge of urban planning}

In France, the Ministry in charge of Urban Planning has supported the evaluation of urban public policies related to sustainable development principles since the 2000s (Fig. 1). Indeed, this Ministry has committed to undertake major revisions of these policies since the signing of the Kyoto Protocol, with the introduction of new regulations developed essentially for technical sectors and, in particular, for the thermal insulation of buildings. These different revisions have gradually resulted in a comprehensive approach to urban development along with the identification of technical, social and environmental parameters. In 2007, the Grenelle de l'Environnement conference invited French territorial authorities to develop eco-neighbourhoods. Even though the concept had not yet been defined and was already subject to criticism - despite the convictions of the Ministry - the Grenelle 2 Law was to reconcile econeighbourhoods with incentive policies in such fields as housing for all, urban renewal, sustainable development, and the participation of the territories in the development of eco-industries. Another objective was to generalize this approach so that local actors would develop these projects as self-contained exceptions to

Table 2

European eco-neighbourhood frameworks in European countries.

\begin{tabular}{|c|c|c|c|c|c|}
\hline Country & Framework & Main objectives & $\begin{array}{l}\text { Name of specific } \\
\text { tools }\end{array}$ & Certification & References \\
\hline $\begin{array}{l}\text { United } \\
\text { Kingdom }\end{array}$ & Eco-town & & $\begin{array}{l}\text { BREEAM } \\
\text { certification }\end{array}$ & $\checkmark$ & Weber and Shah, 2011; Douglas, 2014 \\
\hline Netherlands & National Building Packages & Ecological urban restructuration & & & Melchert, 2007 \\
\hline Sweden & National policies & Integrative urbanization projects & EcoEffect tool & $\checkmark$ & $\begin{array}{l}\text { Erlandson and Levin, 2005; Malmqvist and } \\
\text { Glaumann, 2009; Assefa et al., } 2010\end{array}$ \\
\hline Switzerland & $\begin{array}{l}\text { Control urban sprawl in a } \\
\text { sustainable policies context }\end{array}$ & $\begin{array}{l}\text { Sustainability assessment, } \\
\text { monitoring urban projects }\end{array}$ & SméO tool & $\checkmark$ & Riera Pérez and Rey, 2013 \\
\hline Germany & Sustainable urban planning & Integrative urbanization projects & $\begin{array}{l}\text { DGNB for urban } \\
\text { districts }\end{array}$ & $\checkmark$ & \\
\hline Portugal & Sustainable urban planning & Integrative urbanization projects & ECOXXI & & Moreno Pires et al., 2014 \\
\hline
\end{tabular}




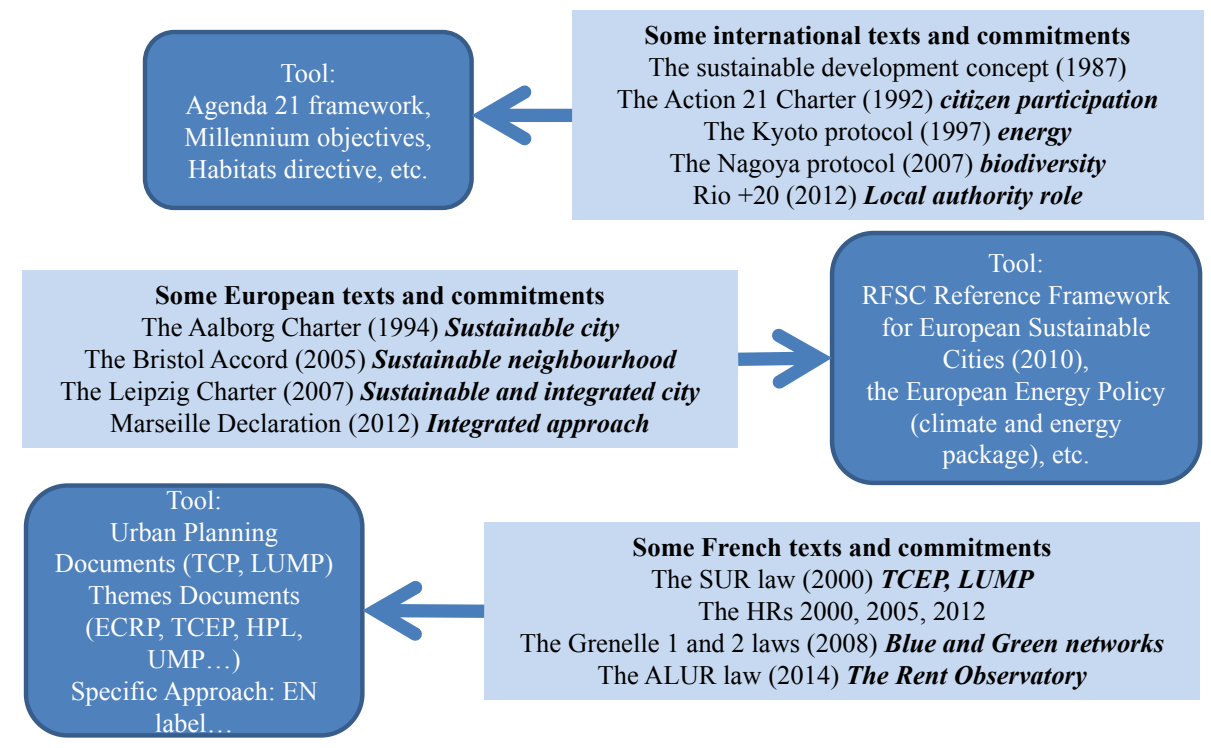

Fig. 1. Hierarchy of regulatory texts in France.

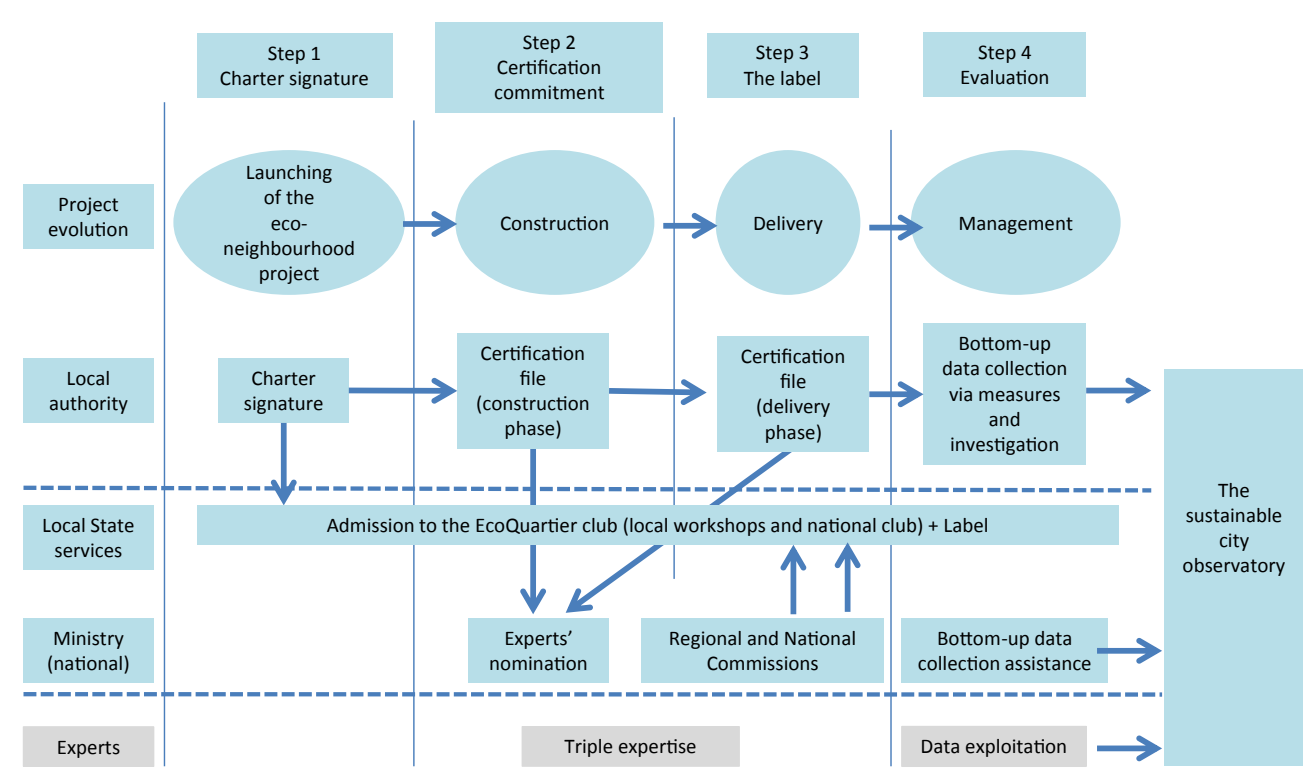

Fig. 2. Diagram of the national certification evaluation method and reference framework.

the wider urban fabric, as is the case in many countries (Ballas, 2013; Cugurolo, 2013; Caprotti, 2014; Joss, 2015). Since 2008, the French government fostered the EcoQuartier approach while more broadly promoting local action that contributes to a coherent national policy favoring the sustainable city (Fig. 2).

The EcoQuartier approach proposed by the French Ministry between 2008 and 2012 remains original in its application of principles of governance, territorial development, quality of life improvement and preservation of the environment - in other words, a sustainable development-based approach. It is further distinguished by its establishment of a bottom-up method that takes into account the local context rather than a top-down one. The Ministry has asked local authorities to share their experiences in terms of urban projects by responding to a list of key topics related to eco-neighbourhoods: social diversity, functionality, multi-generationality, urban density, energy and water savings, soft mobility, waste management, biodiversity enhancement, etc.

\subsection{The reference framework of the City of Paris}

The development of the toolkit titled 'A sustainable urban planning for Paris' originates from a need to translate the regulatory objectives of sustainable development into urban projects by actors involved in planning. A first version of this reference framework was published in 2007, and has constantly and steadily evolved thanks to feedback extending into 2013. The framework takes into account national, regional or local sustainable development benchmarks, and highlights those to which the City of Paris has committed itself. It was designed to improve and generalize sustainable development targets for managing project development 
and urban renewal in Paris, while at the same time introducing an innovative monitoring and evaluation method (Jégou et al., 2012). It applies to every project regardless of its development stage (political proposal, feasibility studies, project design, construction, and operation). Even though the reference framework has no regulatory status, it nonetheless applies to all project development and monitoring in Paris. In addition to the framework, an evaluation identifies projects that show the best performance with respect to each of the sustainable development themes. With the establishment of an interactive platform and experience feedback, the evaluation process ensures the continuous improvement of urban practices in terms of sustainable development (Laurian, 2012).

The willingness to coordinate the Parisian reference framework and the approach of the French Ministry in charge of Urban Planning emerged during the elaboration of the national EcoQuartier certification. When the national document was released in late 2012 , the harmonization of the two approaches was already underway. Each indicator corresponding to one of the twenty parameters of the reference framework is updated as needed and is based on scientific or regulatory developments. The indicators are associated, in the Parisian framework, with a scale of performance ranging from 1 to 5 ("not compliant" to "exemplary") to measure the level of implementation of a given objective for the econeighbourhood. When the evaluation table is complete, a radar diagram provides a view of the levels of performance for the different objectives as well as their evolution during the implementation of the project.

The EcoQuartier label established by the Ministry in charge of Urban Planning and the Parisian reference framework for econeighbourhoods are two answers designed a few years apart for application at two different scales. However, these answers have in common the will to make ubiquitous the introduction of sustainable development principles in project design and implementation. They introduce evaluation and temporality at the core of their approach. These new procedures combine the benefits of a comparative framework at the national level and a necessary regional adaptation of indicators in accordance with local commitments.

\section{From national to local urban planning: the French experience of eco-neighbouring assessment}

Both French policies, national and local, integrate means of assessing urban projects and this assessment achieves a kind of certification. While the Ministry in charge of Urban Planning has developed the national EcoQuartier certification, the City of Paris and other local authorities have designed similar tools, which integrate a large number of parameters dealing with urban sustainability and which are designed to evolve over time.

\subsection{Results of the Parisian example}

Thirteen urban project developments were evaluated between 2010 and 2013 (Jégou et al., 2012). These evaluations were based on the reference framework indicators table given to the project managers, the developers and, in some cases, the design team. Most

Table 3

List of evaluated Parisian projects.

\begin{tabular}{ll}
\hline Year & Operations of urban planning in Paris (see the map on Fig. 4) \\
\hline 2011 & Boucicaut, Gare de Rungis, Saint-Blaise \\
2012 & Binet-Porte Montmartre, Bréguet, Saint-Vincent-de-Paul \\
2013 & Chapelle Internationale, Ourcq-Jaurès \\
\hline
\end{tabular}

of the projects (Table 3) were studied at either operational or construction stage. The Paris map (Fig. 3) shows the location of the Parisian project developments that have been evaluated (2010-2013).

As part of the Parisian approach (Jégou et al., 2012), the evaluation work is initially based on the establishment of a sustainable development profile of the eco-neighbourhood. The goal is to define, during the programming phase, the level to be reached for each of the 20 objectives in the Reference framework. This first profile takes into account the specificities of the local context and is based on a detailed analysis of the project's framework documents (draft declaration, master plan, sustainable development charter, specifications, technical and environmental requirements, etc.), interviews with actors (urban project manager, developer, etc.), and a site visit. Then the future eco-neighbourhood is evaluated during its design phase to analyse the different responses to each of the objectives. Following this initial assessment, the approach intends to achieve several evaluations during the project development, when it is delivered, and $2-5$ years after completion. The proper achievement of the objectives established during the design phase is then verified and the possible project vigilance points corrected. Through the radar charts, the evaluation of the thirteen Parisian urban projects helped to highlight the performance achieved as well as the difficulty to measure or to implement some elements. For instance, some criteria, although territorially relevant, are not always suitable for the programming of each eco-neighbourhood. However, some operational innovations emerged, which gave its full meaning to an evaluation able to take advantage of feedback.

In 2013, two Parisian projects, the Claude Bernard 'Zone d'Aménagement Concertée' (ZAC) (Concerted Development Zone) (Table 3, Fig. 3) and the Fresquel Fontarrabie neighbourhood (Table 3, Fig. 3), were designated as EcoQuartiers. Indeed, they both emphasized the importance of interweaving national and local approaches.

\subsection{The national level}

The result was to look for three-fold project expertise (internal, external and local) to mobilize a community of experts to consider all technical, economic, sociological, urban, environmental and even political parameters related to sustainable urban development. The calls for proposals that were launched (2009 and 2011) focused on various sectors (eco-neighbourhoods in rural areas and villages, eco-neighbourhoods for urban renewal or accessible to different socio-professional population categories, etc.) to capitalize on best practices and to counter prejudice. Finally, the EcoQuartier club was formed to co-define the concept of the econeighbourhood along with the local authority project teams. They were invited to give feedback to the club observatory, whose purpose is to allow the creation of a shared national database. Despite the fact that the word 'eco-neighbourhood' still attracts criticism, the Ministry can nevertheless point to the success of its approach (Citron, 2014): more than 500 local authorities have participated in the EcoQuartier club, which became a place of engagement and exchange between planning and design actors and local authorities. Consequently, it is collectively and iteratively that the definition of the eco-district or eco-neighbourhood concepts has been clarified (Fig. 4).

The 394 local authorities that responded to the call for proposals in 2011 showed projects representing more than 200,000 homes (Table 4), including nearly 66,000 social housing units (31\%). Consequently, eco-neighbourhoods and eco-districts constitute a significant proportion of the French delivery of housing units (309,800 housing units were built in 2010). A quantitative study provides an analysis of the size of the French neighbourhoods: most 


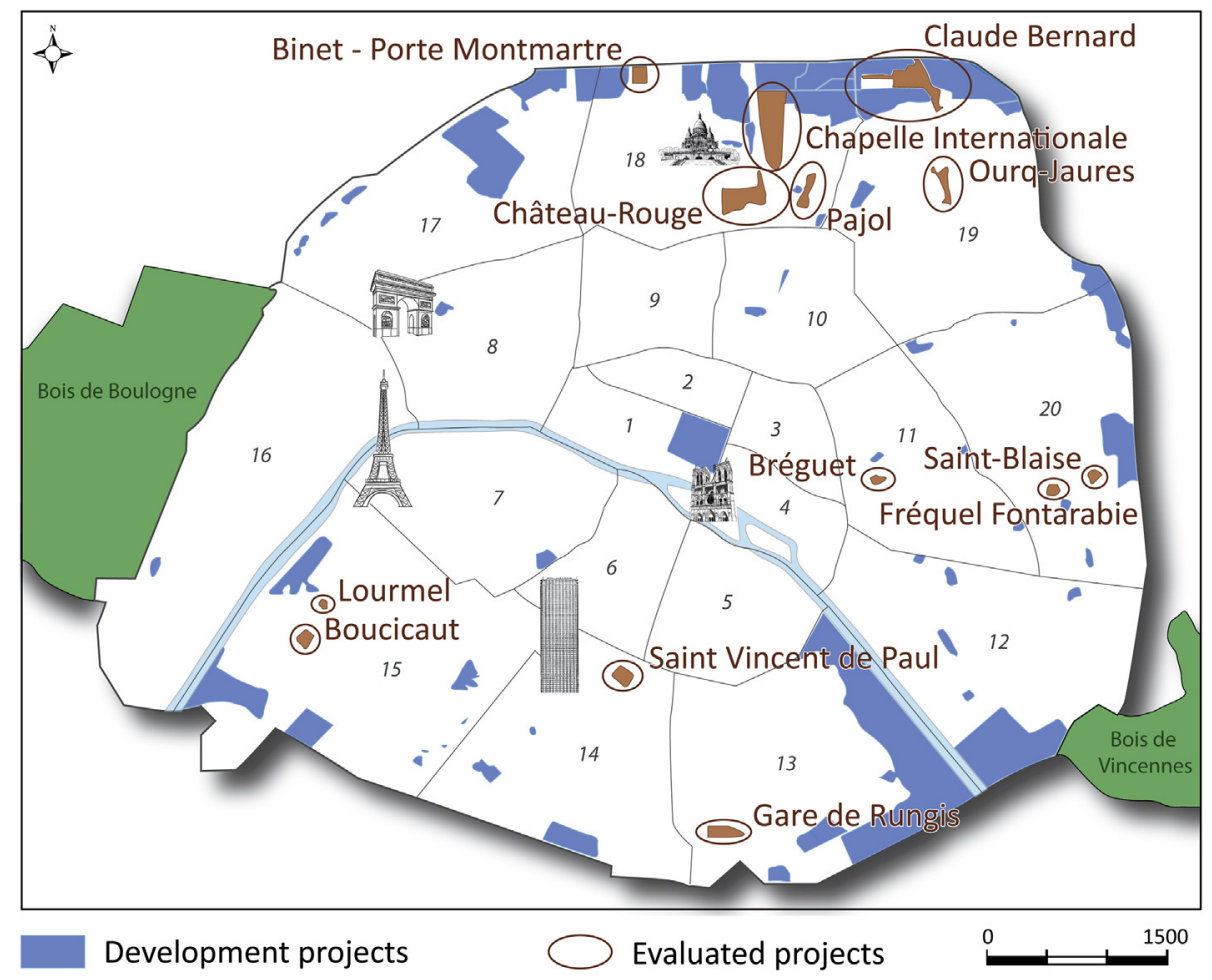

Fig. 3. Location of the thirteen Parisian urban projects that have been evaluated (2010-2013).

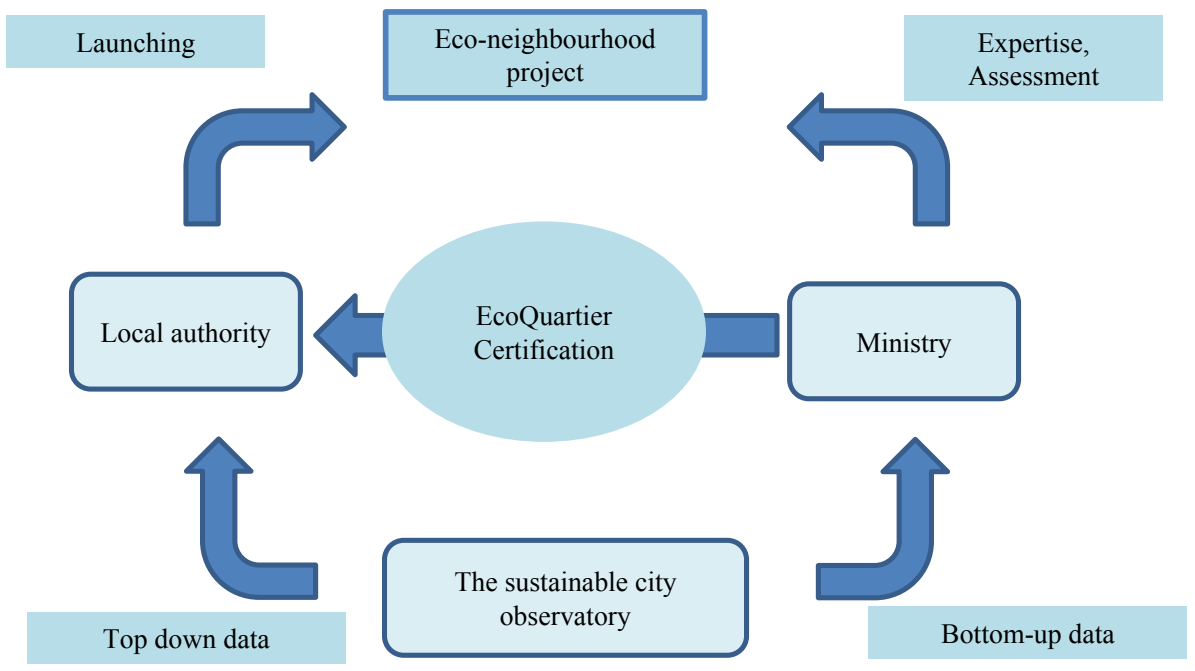

Fig. 4. The virtuous circle of the French neighbourhood framework.

Table 4

Percentage distribution of cities that have undertaken an EcoQuartier certification process by category.

\begin{tabular}{ll}
\hline Cities (inhabitants number) & Percentage (\%) \\
\hline$>100000$ & 12 \\
$20000-100000$ & 27 \\
$2500-20000$ & 42 \\
$<2500$ & 19 \\
\hline
\end{tabular}

of them are important projects with a large number of housing units (Citron, 2014). The first elements suggest that the EcoQuartier approach responds well to the challenges and needs of communities. This approach is also in accordance with objectives set by the State: the delivery of social housing, combatting urban sprawl, fostering territorial solidarity. This is evidence that French eco-neighbourhood projects are not vectors of gentrification, but represent a real commitment to territorial equality on the part of local authorities. The work of the EcoQuartier club, which includes designated local authorities, has not been to seek new evaluation tools, but to offer a broader vision of all existing technical tools. The EcoQuartier grid proposed by the French Ministry in charge of Urban Planning is thus the synthesis of both national voluntary commitments and legislative regulatory commitments. This grid, which includes 20 commitments, is used during the procedure leading to the acquisition of the national certification (Table 5). 
Table 5

The Eco-neighbourhood Charter and its 20 commitments. Evaluation method and National Reference Framework diagrams.

\begin{tabular}{|c|c|c|c|}
\hline $\begin{array}{l}\text { Approach and process: developing } \\
\text { projects differently }\end{array}$ & $\begin{array}{l}\text { Territorial development: galvanizing the } \\
\text { territory }\end{array}$ & $\begin{array}{l}\text { Living environment and use: improving } \\
\text { daily life }\end{array}$ & $\begin{array}{l}\text { Resources preservation and climate change } \\
\text { adaptation: responding to climate and } \\
\text { environmental emergency }\end{array}$ \\
\hline $\begin{array}{l}\text { Realizing projects that respond to } \\
\text { everybody's needs while relying on } \\
\text { territorial resources and constraints }\end{array}$ & $\begin{array}{l}\text { Working in priority on the existing city } \\
\text { and proposing an adapted density to } \\
\text { fight against urban sprawl }\end{array}$ & $\begin{array}{l}\text { Contributing to a local economic } \\
\text { development, balanced and united }\end{array}$ & $\begin{array}{l}\text { Producing an urban environment that } \\
\text { anticipate and adapt to climate change and } \\
\text { risks }\end{array}$ \\
\hline $\begin{array}{l}\text { Formalizing and developing a monitoring } \\
\text { process and a broader governance }\end{array}$ & $\begin{array}{l}\text { Developing diversity (social and } \\
\text { intergenerational) conditions that favor } \\
\text { solidarity and together-living }\end{array}$ & $\begin{array}{l}\text { Favoring the diversity of functions for } \\
\text { short distances territory }\end{array}$ & $\begin{array}{l}\text { Aiming for energy savings and source } \\
\text { diversity for the benefit of renewable and } \\
\text { recovered energy }\end{array}$ \\
\hline $\begin{array}{l}\text { Integrating an approach related to global } \\
\text { costs when choosing investments }\end{array}$ & $\begin{array}{l}\text { Insuring a healthy and safe living } \\
\text { environment }\end{array}$ & $\begin{array}{l}\text { Optimizing resources and material } \\
\text { consumptions, and developing local } \\
\text { industries and short networks }\end{array}$ & $\begin{array}{l}\text { Limiting waste production, developing and } \\
\text { strengthening recycling networks and } \\
\text { waste upgrading }\end{array}$ \\
\hline $\begin{array}{l}\text { Considering users' practices and } \\
\text { managers' constraints for design } \\
\text { choices }\end{array}$ & $\begin{array}{l}\text { Developing an architectural and an } \\
\text { urban quality that reconciles intensity } \\
\text { and quality of life }\end{array}$ & $\begin{array}{l}\text { Favoring soft mobility and public } \\
\text { transportation to reduce automobile } \\
\text { dependency }\end{array}$ & $\begin{array}{l}\text { Preserving water resources and ensuring } \\
\text { qualitative and efficient management }\end{array}$ \\
\hline $\begin{array}{l}\text { Developing evaluations and continuous } \\
\text { improvement approaches }\end{array}$ & $\begin{array}{l}\text { Highlighting the local heritage (natural } \\
\text { and built), the history and the } \\
\text { neighbourhood identity }\end{array}$ & $\begin{array}{l}\text { Favoring the digital transition, while } \\
\text { facilitating networks shifting and } \\
\text { innovating services }\end{array}$ & $\begin{array}{l}\text { Preserving and highlighting biodiversity, } \\
\text { soils and natural environments }\end{array}$ \\
\hline
\end{tabular}

Since 2008, under the leadership of the State, a common vision of the eco-neighbourhood has gradually emerged in France. It is an urban development that aims to build a mixed city, while including urban stakeholders and consultations with residents, and providing an environment that favours quality of life while reducing its ecological footprint. Designing an eco-neighbourhood means finding the right response to specific issues (housing, economic activity, equipment, energy efficiency, welfare, etc.) and an urban form (from the detached house to denser blocks) while avoiding the "showcase effect".

The French national EcoQuartier certification does not provide any model or 'all inclusive' answers, but emphasizes a common project definition regardless of its stage of completion within context. All local authorities are invited to commit to a voluntary and ambitious approach, which responds to the specific challenges of their local area. The label should provide quality guarantees, based on fundamental requirements, and is granted after going through a process that is transparent and easily understood.

The EcoQuartier certification is based on three objectives identified as essential by all experts who have contributed to the development of its label, whether employed as development professionals within the public or the private sector. These three objectives are: to encourage the emergence of projects, to sustain the ambitions outlined in the project objectives, and to guarantee performance. If the first two goals seem implicit in the certification process, the third one that guarantees the quality of the project provides a whole new dimension. The objective is not to measure the characteristics of a product, or to calculate the technical performance of a building or buildings, or even to certify the quality of a process, but to identify whether a development project responds to the cross-cutting and holistic challenge of creating sustainable cities. The objectives are also to check if the goals set by the client (community developer, etc.) are shared with other actors (promoters, sponsors, managers, etc.), and whether they are attained and managed over time. One difficulty is related to the crosscutting aspect of this approach, as project developments are required to provide responses to the 20 commitments established by the EcoQuartier certification (Table 5 ). The evaluation should therefore focus equally on social, economic, technical and societal commitments, and even management and consultation aspects.

To qualify, the local authority must display a complete or almost (more than 50\%) complete development project. What then interests the Ministry is not to certify a project, or to provide an image of what a future eco-neighbourhood could be, but rather to measure the neighbourhood's progress in such areas as its completeness and liveliness, with inhabitants, housing, shops, public facilities, offices, public spaces, living spaces, and meeting places. The strength of this evaluation is then to measure or qualify tangible and visible results (Fig. 4).

\section{Discussion}

The analysis of the approaches of both the French Ministry in charge of Urban Planning and the City of Paris allows not only some specific observations on the evaluation of eco-neighbourhoods, but also more generally on sustainable urban development.

\subsection{Constraints linked to the eco-neighbourhood evaluation process}

The evaluation and certification process does not aim to control levels of performance, but to identify good results and tools that have achieved the desired objectives, and to establish possible corrective measures, when appropriate, in terms of costs (Holden, 2006).

One difficulty is related to the eco-neighbourhood border, which cannot be reduced to a regulatory perimeter. The econeighbourhood must go beyond these artificial boundaries, which are not related to the reality of an urban development, to create a degree of territorial leverage, and to provide operational and sustainable solutions to the identified challenges. Finally, the evaluation of eco-neighbourhoods is not a method of judging the performance achieved by a project compared to a fictitious econeighbourhood model, but a process that aims to assess whether the responses provided by local authorities still honour the ambitions of eco-neighbourhoods in a thoroughgoing way.

Nevertheless, it appears that sharing this information about evaluation can sometimes trigger the reluctance of elected officials, as the time frames of projects do not always correspond to the electoral agenda.

Administrative and institutional constraints on the evaluation of eco-neighbourhoods are essentially related to human and financial resources provided by the local authority, so as to ensure the continuous monitoring of urban projects and the necessary crosscutting approach between departments. In response to the first point, the Ministry decided in 2014 to grant a $€ 30,000$ subsidy to each local authority that obtained the EcoQuartier certification thanks to the implementation of the monitoring and evaluation method.

Regulatory constraints are related to the different levels of application planning documents, (whether national, regional, 
departmental or municipal) and their necessary adaptation to multiple sustainable development issues. Fig. 4 presents the hierarchy of regulatory texts in France, and underlines the complexity of regulatory layers that govern operational planning practices, from the European to the municipal level.

The integrated eco-neighbourhood approach aims to simplify the reading of these multiple layers by placing the urban project at the core of the evaluation grids. From a technical point of view, the use of monitoring indicators is particularly complex (Holden, 2006). On the one hand, the calculation of some indicators, such as well-being and health data, requires access to some information that is difficult to obtain (Lawrence, 2008; Wells and Donofrio, 2011; Ballas, 2013). Similarly, if the energy consumption of a building can be easily assessed during the design and operational phases, the evaluation of GHG emissions or sustainable mobility within a neighbourhood is more difficult to measure (Paiho et al., 2014). On the other hand, some indicators are simple to measure, but are not representative of the area of concern. For example, the number of trees located within the perimeter of an econeighbourhood is easy to determine, but is insufficient to deduce the level of biodiversity of the project (Andersson, 2006; Grove et al., 2006; Sze and Gambirazzio, 2013). Evaluations conducted by the City of Paris helped to highlight a lack of data depending on the phase of the project, which sometimes made it impossible to evaluate some objectives. Shifting indicators require regular updates to avoid becoming obsolete, which further complicates the monitoring of evaluation over time. Finally, some objectives are not taken into account for the design of projects, as some actors consider them as a low priority.

Contextualizing evaluations in relation to the capabilities of the actors of urban development plays a significant role in assessing the achievement of objectives. Moreover, the hierarchy of territorial issues has resulted, in some cases, in a weighting of indicators (Holden, 2006): the use of a renewable energy indicator can, for instance, become a priority over an indicator of the increase of waste recycling. Similarly, the dense Parisian territory presents advantages related to its extensive public transport networks, but is more constrained when it comes to the renovation of old buildings, or the development of ecological corridors. Thus, the specificity of the EcoQuartier national certification is to provide an evaluation method able to adapt to each territory and project development, relying on common indicators.

A cultural component can be added to political, administrative and institutional, regulatory and technical constraints. Firstly, the means of understanding the eco-neighbourhood can sometimes make it difficult to perform an evaluation, and thus highlights all of the contradictions associated with this concept. In response to this conceptual limitation, the adoption of an integrated approach and a multi-criteria evaluation helps to better define the complexities of an eco-neighbourhood. This is a result of interweaving technical, sociological and economic approaches for a given project. Secondly, it seems essential to achieve a multi-scale evaluation. If the eco-neighbourhood represents a step towards the sustainable city, one should not only evaluate its performance, but also that of the surrounding neighbourhoods and of the city of which the eco-neighbourhood is a part; this includes the assumption that the eco-neighbourhood performance must also be able to improve the overall performance of the city. The issue is finally to be able to adopt an ecological and technical logic, rewarding life and landscape quality where populations can contribute to the management of the city (community gardens, urban agriculture, etc.), along with an urban management logic based on engineering models (Despommier, 2011; Ahat et al., 2013; Kien and Fernandez, 2014).

\subsection{Assets related to the eco-neighbourhood evaluation process}

The difficulties encountered during the first evaluations do not cancel the multiple benefits that such an approach presents; it is actually quite the contrary.

Obtaining the EcoQuartier label is rewarding for elected officials, as the evaluation of eco-neighbourhoods can highlight the strengths of a project, including the mode of governance. Moreover, the results induce a leverage effect in terms of innovative practices applied in the territory (Pretty, 2003). The EcoQuartier certification is also a tool for comparing and sharing projects between territories.

From an administrative and institutional perspective, the approach has demonstrated the ability of urban planning and design actors to evolve, to change their practices, to question and challenge themselves under sometimes very tight schedule conditions. While in the 2000's it was still difficult to evoke and imagine what environmental quality and sustainable development could be for urban projects; today it is clear that applying the sustainability principle to urban projects has become a wellestablished practice. The desired levels of performance certainly vary depending on the territories, but evaluations have improved and generalized these levels of performance consistently ever since they have existed.

Recent regulatory changes in French legislation have profoundly altered texts related to urban development and renewal since 2000 , such as the SRU law (December 2000), the Grenelle 2 law (July 2010), or even the ALUR law (January 2014), also called the Housing and Renovated Urban Environments access law. In other words, the city today is no longer planned as it was in the late 1990s. What has changed is the growing awareness of the environmental and landscape impacts of urban projects on territories, as well as the new role played by the concept of sustainability i projections ranging from ten to nearly one hundred years. As we have seen, the sustainability of many cities largely depends on the synergy between the selected targets. This is fully demonstrated by the regulatory role of nature (Xuan et al., 2012). In addition, any contracting local authority must now estimate the maintenance and management costs of buildings, public spaces and green spaces. This opens up new ideas, not only on how to introduce sustainability performance concepts for project design and implementation over time, but also about public spaces and the life cycles of buildings. Multiple studies and research programmes have been undertaken to better measure the levels of performance achieved by these new neighbourhoods. They also better anticipate future urban developments that combine a high level of engineering and technology, such as buildings managed entirely by computers (Holden, 2006; Ding, 2008; Ahat et al., 2013; Kien and Fernandez, 2014).

Reflections related to sustainable urban development provided the opportunity to re-examine practices and techniques that seemed established. This is for example the case of Paris's central heating and cooling networks, where the pooling of energies could result in significant savings. Local contracting authorities naturally call upon the services of the research community to respond to the many questions that arise, to establish new partnerships with private actors, and thus to introduce new modes of governance for eco-neighbourhoods.

\section{Conclusion}

The French government is seeking to provide a framework and a method for the evaluation of the performance of econeighbourhoods. However, it does not consider there is a single and fixed example for the eco-neighbourhood. The French idea of 
the eco-neighbourhood responds to a political project, which involves all dimensions of sustainable development and even includes citizens' participation in project development. These dimensions should be evaluated in every phase of the life cycle of projects, while becoming a guarantee of objective achievement for the political and civil society. We are far from the "edge cities" fully funded by private groups which aim to produce either luxury neighbourhoods for urban gentrification, or laboratories that improve the image of elected officials in a race for technical performances (Bulkeley and Castan Broto, 2012; Cugurolo, 2013; Caprotti, 2014). For many public and private actors in urban development, there may be a confusion or amalgamation between expertise and evaluation. Many methods considered to be part of evaluation are in fact only tools of expertise whose goal is to monitor the implementation of development projects. We want to clarify the distinction between these two concepts, which are both fundamental, but present different objectives: tools of expertise aim to qualify projects based on elements and data provided by the project owners, including the means they use to achieve their ambitions, whereas evaluations aim to develop tools to measure the achievement of objectives, and to guarantee the quality of projects over time once they are completed. Therefore, the data needed for evaluating a project are not provided a priori by the project owner, but by active methods of information analysis, collected either by measurements or by investigations.

In France, the first feedback concerning the establishment of standards and procedures for the evaluation of econeighbourhoods reflects on the extensive efforts undertaken, not only by governments but also by public or private actors, to design an eco-neighbourhood model. The comprehensive approach that incorporates environmental, economic and social parameters into the development of these urban infrastructures demonstrates that various methods of designing successful, sustainable city experiences are available. If these standards and methods of evaluation essentially deal with the support of urban design projects, it also seems important to develop frameworks for the sustainable management of eco-neighbourhoods in contexts such as urban expansion or renewal. In the future, evaluation must become an instrument of policy and of sustainable development for the city of tomorrow.

French approaches involve the implementation of econeighbourhood evaluations that stem from an integrated strategy based on sustainable development principles. The fact that urban projects are evaluated is concomitant with an improvement in territorial management processes and aims to extend urban infrastructure durability. This subject, currently thriving in the scientific literature, shows that the French experience of eco-neighbourhood development is original because, unlike most comparable projects implemented in the world - which chiefly represent experimental sites - the French model particularly emphasizes the spreading and generalisation of eco-neighbourhoods, which are presented as leverage for urban sustainability (Winkelman, 2007; Douglas, 2014).

While our goal here was to report on the political will that it took, at national and local level, to design a system of evaluation, the study has also revealed what a French eco-neighbourhood model might look like. Even though this model is complex and non-standardised, it aims to integrate various components of urban sustainability. After the Conference of the Parties on Climate Change of 2015, it seems appropriate to consider this model as a contribution to the methodological basis through which any urban construction or renewal might be approached, as well as a contribution to the fight against global warming and the energy poverty of certain populations. Moving beyond the role of the developer and the planner, eco-neighbourhoods can merge with the urban fabric inherited from the past, and can be a model for all urban projects. As urban populations will account for almost two thirds of world population by 2050, there thus stands before us an issue that concerns not only planners, but also civil society as a whole.

\section{References}

Ahat, M., Ben Amor, S., Bui, A., 2013. Agent-based modelling of ecodistricts with smart grid. Advanced computational methods for knowledge engineering. Stud. Comput. Intell. 479, 307-318.

Andersson, E., 2006. Urban landscape and sustainable cities. Ecol. Soc. 11, 34

Assefa, G., Glaumann, M., Malmqvist, T., Eriksson, O., 2010. Quality versus impact: comparing the environmental efficiency of building properties using the EcoEffect tool. Build. Environ. 45, 1095-1103.

Bai, Y., Wang, R., Jin, J., 2011. Water eco-service assessment and compensation in a coal mining region - a case study in the Mentougou District in Beijing. Ecol. Complex. 8, 144-152.

Ballas, D., 2013. What makes a happy city? Cities 32, 39-50.

Bin, G., Parker, P. 2012. Measuring buildings for sustainability: comparing the initial and retrofit ecological footprint of a century home-The REEP House. Appl. Energy 93, 24-32.

Boulanger, P.M., Bréchet, T., 2005. Models for policy making in sustainable development: the state of the art and perspectives for research. Ecol. Econ. 55, 337-350.

Boulanger, P.M., Lazzeri (Eds.), 2006. Les indicateurs territoriaux de développement durable. L'Harmattan, Paris, p. 323.

Boutaud, B., 2009. Quartier durable ou éco-quartier? Cybergeo Eur. J. Geogr. http:// dx.doi.org/10.4000/cybergeo.22583. http://cybergeo.revues.org/22583.

Bulkeley, H., Castán Broto, V., 2012. Government by experiment? global cities and the governing of climate change. Trans. Inst. Br. Geogr. 38, 361-375.

Burdova, E.K., Vilcekova, S., 2012. Building environmental assessment of construction and building materials. J. Front. Constr. Eng. 1, 1-17.

Caprotti, F., 2014. Critical research on eco-cities? A walk through the Sino-Singapore Tianjin Eco-City, China. Cities 36, 10-17.

Chambers, N., Simmons, C., Wackernagel, M., 2004. Sharing Nature's Interest: Ecological Footprints as an Indicator of Sustainability. Sterling Earthscan, London. http://www.earthscan.co.uk/.

Citron, P., 2014. Les écoquartiers: une exception française de plus? Analyse quantitative de 186 projets issus de l'appel à projet ÉcoQuartier 2011. In: Behmessous, F., Bonneval, L., Coudroy de Lille, L., Ortar, N. (Eds.), Logements et politique(s). L'Harmattan, Paris, pp. 107-124.

Chelzen, H., Pech, P., 2011. Quelle image de la ville pour un projet de développement urbain durable ? L'exemple d'Aubervilliers, vol. 11. Vertigo. http://dx.doi.org/ 10.4000/vertigo.11509. http://vertigo.revues.org/11509.

Cole, R.J., 1998. Emerging trends in building environmental assessment methods. Build. Res. Inf. 26, 3-16.

Cugurolo, F., 2013. How to build a sandcastle: an analysis of the genesis and development of Masdar City. J. Urban Technol. 20, 23-37.

Despommier, D., 2011. The vertical farm: controlled environment agriculture carried out in tall buildings would create greater food safety and security for large urban populations. Journal für Verbrauchershutz und Lebensmittelsicherheit 6 , 233-236.

Ding, G.K.C., 2008. Sustainable construction: the role of the environmental assessment tool. J. Environ. Manag. 8, 451-464.

Douglas, I., 2014. The political filter in the local implementation of initiatives relating to urban ecology. Landsc. Urban Plan. 125, 312-319.

Erlandson, M., Levin, P., 2005. Environmental assessment of rebuilding and possible performance improvements effect on a national scale. Build. Environ. 40, 1459-1471.

Ewing, B.R., Hawkins, T.R., Wiedmann, T.O., Galli, A., Ertug Ercin, A., Weinzettel, J., Steen-Olsen, K., 2012. Integrating ecological and water footprint accounting in a multi-regional input-output framework. Ecol. Indic. 23, 1-8.

Forsberg, A., Von Malmborg, F., 2004. Tools for environmental assessment of the built environment. Build. Environ. 39, 223-228.

Gonzalez, M.J., Navarro, J.G., 2006. Assessment of the decrease of $\mathrm{CO}_{2}$ emissions in the construction field through the selection of materials: practical case study of three houses of low environmental impact. Build. Environ. 41, 902-909.

Gonzalez, P.A., Zamarreno, J.A., 2005. Prediction of hourly energy consumption in buildings based on a feedback artificial neural network. Energy Build. 37, 595-601.

Grimm, N.B., Faeth, S.H., Golubiewski, N.E., Redman, C.L., Wu, J., Bai, Z., Briggs, J.M., 2008. Global change and the ecology of cities. Science 319, 756-760. http:// dx.doi.org/10.1126/science.1150195.

Grove, J.M., Troy, A.R., O'Neil-Dunne, J.P., Burch Jr., W.R., Cadenasso, M.L, Pickett, S.T.A., 2006. Characterization of households and its implications for the vegetation of urban ecosystems. Ecosystems 9, 578-597.

Gustavsson, L., Joelsson, A., Sathre, R., 2010. Life cycle primary energy use and carbon emission of an eight-storey wood-framed apartment building. Energy Build. 42, 230-242.

Holden, M., 2006. Urban indicators and the integrative ideals of cities. Cities 23, $170-183$. 
Holden, M., 2013. Sustainable indicator systems within urban governance: usability analysis of sustainability indicator systems as boundary objects. Ecol. Indic. 32, 89-96.

Holman, N., 2009. Incorporating local sustainability indicators into structures of local governance: a review of the literature. Local Environ. 14, 365-375.

Hong, T., Kim, H., Kwak, T., 2012. Energy-saving techniques for reducing $\mathrm{CO}_{2}$ emissions in elementary schools. J. Manag. Eng. 28, 39-50.

Jégou, A., About de Chastenet, C., Augiseau, V., Guyot, C., Monaco, F.-X., Pech, P., 2012. L'évaluation par indicateurs: un outil nécessaire d'aménagement urbain durable ? Réflexions à partir de la démarche parisienne pour le géographe et l'aménageur. Cybergeo Eur. J. Geogr. 625 http://dx.doi.org/10.4000/cybergeo.25600. http://cybergeo.revues.org/25600.

Jégou, A., 2011. Territoires, acteurs et enjeux des dynamiques de durabilité urbaine: le cas de la métropole parisienne, p. 721 thèse de géographie de l'université Paris 1. http://tel.archives-ouvertes.fr/tel-00681586.

Joss, S., 2015. Eco-cities and sustainable urbanism. International Encyclopedia of the Social \& Behavioral Sciences, pp. 829-837.

Junnila, S., Horvath, A., Guggemos, A.A., 2006. Life-cycle assessment of office buildings in Europe and the United States. J. Infrastruct. Syst. 12, 10-17.

Kien, T., Fernandez, J.E., 2014. Alternative urban technology for future low-carbon cities: a demonstration project review and discussion. In: Gheorge, A.V., Masera, M., Katina, P.F. (Eds.), Infranomics. Sustainability, Engineering Design and Governance, Topics in Safety, Risk, Reliability and Quality, vol. 24, pp. 165-193.

Kneifel, J., 2010. Life-cycle carbon and cost analysis of energy efficiency measures in new commercial buildings. Energy Build. 42, 333-340.

Komeily, A., Srinivasan, R.S., 2015. A need for balanced approach to neighbourhood sustainability assessments: a critical review and analysis. Sustain. Cities Soc. 18, $32-43$.

Korolijaa, I., Marjanovic-Haldburdb, L., Zhanga, Y., Hanbya, I., 2011. Influence of building parameters and HVAC systems coupling on building energy performance. Energy Build. 43, 1247-1253.

Laurian, L., 2012. Paris, France: a 21st-century eco-city. In: Beatley, T. (Ed.), Green cities of Europe, pp. 29-64.

Lawrence, R.J., 2008. Urban environmental health indicators: appraisal and policy directives. Rev. Environ. Health 23, 299-325.

Li, D.Z., Chen, H.X., Hui, E., Zhang, J.B., Li, Q.M., 2013. A methodology for estimating the life-cycle carbon efficiency of a residential building. Build. Environ. 59, $448-455$.

Li, D.Z., Hui, E., Leung, B., Li, Q.M., Xu, X., 2010. A methodology for eco-efficiency evaluation of residential development at city level. Build. Environ. 45, 566-573.

Li, L., Zhang, B., Li, S., 2011. Quantitative study of eco-city in Northwest China. Proced. Eng. 21, 345-353.

Malmqvist, T., Glaumann, M., 2009. Environmental efficiency in residential buildings - a simplified communication approach. Build. Environ. 44, 937-947.

Mascarenhas, A., Coelho, P., Subtil, E., Ramos, T.B., 2010. The role of common local indicators in regional sustainability assessment. Ecol. Indic. 10, 646-656.

McMahon, S.K., 2002. The development of quality of life indicators - a case study from the City of Bristol, UK. Ecol. Indic. 2, 177-185.

Melchert, L., 2007. The Dutch sustainable building policy: a model for developing countries? Build. Environ. 42, 893-901.

Monahan, J., Powell, J.C., 2011. An embodied carbon and energy analysis of modern methods of construction in housing: a case study using a lifecycle assessment framework. Energy Build. 43, 179-188.

Moreno Pires, S., Fidelis, T., Ramos, T.B., 2014. Measuring and comparing local sustainable development through common indicators: constraints and achievements in practice. Cities 39, 1-9.

Neirotti, P., De Marco, A., Cagliano, A.C., Mangano, G., Scorrano, F., 2014. Current trends in smart city initiatives: some stylised facts. Cities 38, 25-36.

Ouyang, J.L., Wang, C.Y., Li, H.F., Hokao, K., 2011. A methodology for energy-efficient renovation of existing residential buildings in China and case study. Energy
Build. 43, 2203-2210.

Paiho, S., Hoang, H., Hedman, A., Abdurafikov, R., Sepponen, M., Meinander, M., 2014. Energy and emission analyses of renovation scenarios of a Moscow residential district. Energy Build. 76, 402-413.

Pandis, I.S., Brandt, N., 2011. The development of a sustainable urban district in Hammarby Sjöstad, Stockholm, Sweden? Environ. Dev. Sustain. 13, 1043-1064.

Pickett, S.T.A., Cadenasso, M.L., Grove, J.M., Boone, C.G., Groffman, P.M., Irwin, E., Kaushal, S.S., Marshall, V., McGrath, B.P., Nilon, C.H., Pouyat, R.V., Szlavecz, K., Troy, A., Warren, P., 2011. Urban ecological systems: scientific foundations and a decade of progress. J. Environ. Manag. 92, 331-362.

Premalatha, M., Tauseef, S.M., Abbasi, T., Abbasi, S.A., 2013. The promise and the performance of the world's first zero carbon eco-cities. Renew. Sust. Energ. Rev. 25, 660-669.

Pretty, J., 2003. Social capital and collective management of resources. Science 302, 1912-1916.

Riera Pérez, M.G., Rey, E., 2013. A multi-criteria approach to compare urban renewal scenarios for an existing neighborhood. Case study in Lausanne (Switzerland). Build. Environ. 65, 58-70.

Rinne, S., Syri, S., 2013. Heat pumps versus combined heat and power production as $\mathrm{CO}_{2}$ reduction measures in Finland. Energy 57, 308-318.

Solís-Guzmán, J., Marrero, M., Ramirez-De-Arellano, A., 2013. Methodology for determining the ecological footprint of the construction of residential buildings in Andalusia (Spain). Ecol. Indic. 25, 239-249.

Smyth, R.L., Watzin, M.C., Manning, R.E., 2007. Defining acceptable levels for ecological indicators: an approach for considering social values. Environ. Manag. 39, 301-315.

Sze, J., Gambirazzio, G., 2013. Eco-cities without ecology: constructing ideologies, valuing nature. In: Pickett, S.T.A., Cadenasso, M.L., McGrath, B. (Eds.), Resilience in Ecology and Urban Design Future City. Sprigner Science+Business Media, Dordrecht, pp. 289-297.

Tanguay, G.A., Rajaonson, J., Lefebvre, J.F., Lanoie, P., 2010. Measuring the sustainability of cities: an analysis of the use of local indicators. Ecol. Indic. 10, 407-418.

Teng, J., Wu, X., 2014. Eco-footprint-based life eco-efficiency assessment of building projects. Ecol. Indic. 39, 160-168.

Utama, A., Gheewala, S.H., 2008. Life cycle energy of single landed houses in Indonesia. Energy Build. 40, 1911-1916.

Walsh, B., 25 Jan 2011. Masdar City: the world's greenest city? Time Mag. Available http://www.time.com/time/health/article/0,8599,2043934,00.html.

Wang, R., Zhou, T., Hu, D., Li, F., Liu, J., 2011. Cultivated eco-sustainability: socialeconomic-natural complex ecosystem case studies in China. Ecol. Complex. 8, 273-283.

Wangel, J., Walhagen, M., Malmqvist, T., Finnveden, G., 2016. Certification systems for sustainable neighbourhoods: what do they really certify? Environ. Impact. Assess. 56, 200-213.

Weber, C., Shah, N., 2011. Optimisation based design of a district energy system for an eco-town in the United Kingdom. Energy 36, 1292-1308.

Wells, N.M., Donofrio, G.A., 2011. Urban planning, the natural environment and public health. Encycl. Environ. Health. http://dx.doi.org/10.1016/B978-0-44452272-6.00480-3.

Winkelman, S., 2007. Comment on Stone: could the worst of times for the planet be the best of times for planning? J. Am. Plan. Assoc. 73, 418-420.

Xiaosai, H., Yi, L., Tianwei, L., Jining, C., 2013. Does the rapid development of China's urban residential buildings matter for the environment? Build. Environ. 64, 130-137.

Xuan, W., Su, J., Shan, S., Zhang, Y., 2012. Urban ecological regulation based on information entropy at the town scale. A case study on Tongzhou district, Beijing City. Proced. Environ. Sci. 13, 1155-1164.

Zhao, J., Zhu, N., Wu, Y., 2009. The analysis of energy consumption of a commercial building in Tianjin, China. Energy Policy 37, 2092-2097. 